Красинский Владислав Вячеславович кандидат юридических наук, эксперт Российского общественного института избирательного права (РОИИП)

\title{
СООТНОШЕНИЕ МЕЖДУНАРОДНОГО И НАЦИОНАЛЬНОГО АСПЕКТОВ В ПРАВОВОМ РЕГУЛИРОВАНИИ ИЗБИРАТЕЛЬНОГО ПРОЦЕССА
}

Красинский В.B. Соотношение международного и национального аспектов в правовом регулировании избирательного процесса // Современное право. 2011. № 4. С. 21-25; www.krasinskiy.ru

Аннотация: В статье анализируется правовая регламентация избирательного процесса. Автор изучает международные избирательные стандарты и показывает их значение регулирования выборов.

Ключевые слова: международное правовое регулирование выборов, международные избирательные стандарты, избирательный процесс, правовое регулирование выборов в интересах защиты конституционного строя.

The article examines a legal regulation of the elections. The author studies the international electoral standards and shows their importance for the legal regulation of the elections.

Key words: international legal regulation of the elections, international electoral standards, electoral process, legal regulation of the elections.

В соответствии с пунктом 1 Декларации принципов международного наблюдения за выборами (ООН, 27 октября 2005 г.) права граждан избирать и быть избранными в ходе периодических, подлинно демократических выборов являются международно-признанными правами человека. Частью международного наблюдения за соблюдением прав человека выступает международное правовое регулирование избирательного процесса и наблюдение за выборами.

Международное правовое регулирование представляет собой властное воздействие государств на межгосударственные отношения с помощью норм международного права. Международное правовое регулирование осуществляется путем определения стандартов, моделей обязательного, возможного и недопустимого поведения, а также побуждения субъектов следовать этим стандартам ${ }^{1}$. Данный вид регулирования направлен на

${ }^{1}$ Лукашук И.И. Международное право. Общая часть. М.: Изд-во БЕК, 1997. С. 161. Более подробно процесс международного правового 
выработку международных правовых обязательств участников межгосударственных отношений.

Особенностями международного правового регулирования являются согласие участников правотворчества с нормативными предписаниями, формализованность, определенность содержания, относительная стабильность по сравнению с другими видами социального регулирования, возможность прогнозирования результатов правотворческой деятельности.

Главное преимущество международного правового регулирования заключается в том, что оно обеспечивает взаимодействие государств в правотворческом процессе и опирается на их поддержку. Источником международного регулирования служит суверенная власть государствучастников правотворчества.

Следует согласиться с И.И. Лукашуком в том, что «государственновластный момент в международном правовом регулировании имеет внутренний и международный аспекты» ${ }^{1}$. Внутренний аспект состоит в подчинении деятельности государственных органов, индивидов, организаций государственной воле, с тем, чтобы эта деятельность не противоречила задачам участия государства в системе международного правового регулирования. Международный аспект государственно-властного момента этого регулирования состоит в использовании каждым субъектом имеющихся у него государственно-властных средств для сотрудничества с другими государствами в создании и осуществлении международных правовых норм, а в случае необходимости и для применения мер принуждения к правонарушителю.

регулирования рассматривается в работе Лукашук И.И. Международноправовое регулирование международных отношений. М.: Международные отношения, 1975.

1 Лукашук И.И. Международное право. Общая часть. М.: Изд-во БЕК, 1997. C. 164. 
Подсистема международного правового регулирования избирательного процесса является частью системы международного правового регулирования.

Изучение международного аспекта правового регулирования избирательного процесса целесообразно начать с анализа международных избирательных стандартов.

Международные избирательные стандарты представляют собой общепризнанные принципы и нормы международного права, относящиеся к организации демократического избирательного процесса, в том числе международные обязательства государств в области избирательных прав и свобод человека и гражданина. В Руководстве по мониторингу участия женщин в выборах (ОБСЕ/БДИПЧ, Варшава, 2005 г.) под международными стандартами понимаются «обязательства государств, имеющие непосредственное отношение к выборам» 1 .

Международные стандарты носят общий характер, излагая принципы, которым государства должны следовать. Именно эта особенность отличает международные стандарты от общепринятой «добросовестной» практики, следование которой желательно, но не обязательно.

В международной практике отсутствуют согласованные подходы к классификации международных избирательных стандартов. Единообразное понимание международных стандартов в электоральной сфере не выработано даже в рамках отдельных международных организаций.

Так, в Отчете ОБСЕ/БДИПЧ «Существующие обязательства по проведению демократических выборов в государствах - участниках ОБСЕ» (Варшава, 30 июня 2003 г.) говорится об общепринятых нормах, содержащихся в документах $\mathrm{OOH}$ (прежде всего, во Всеобщей декларации прав человека 1948 г. и Международном пакте о гражданских и политических правах 1966 г.); об обязательствах ОБСЕ (обязательства из

${ }^{1}$ Международные избирательные стандарты. Сб. документов / Отв. ред.: доктор юрид. наук В.И. Лысенко. М.: ЦИК России, 2009. С. 702. 
Документа Копенгагенского совещания Конференции по человеческому измерению СБСЕ 1990 г.); о принципах, предусмотренных другими региональными документами на территории ОБСЕ (Конвенцией о стандартах демократических выборов, избирательных прав и свобод в государствах участниках СНГ; Кодексом хорошей практики в сфере выборов Венецианской комиссии); об общих стандартах практической деятельности, принятых среди государств - участников ОБСЕ $^{1}$. В дополнение к изложенным избирательным стандартам предлагается рассматривать примеры положительной практики. $\mathrm{K}$ сожалению, предложенный в упомянутом Отчете перечень международных стандартов не раскрывается и в силу этого малопригоден для практического применения.

Руководство для внутренних наблюдателей за выборами (ОБСЕ/БДИПЧ, Варшава, 2004 г.) называет такие международные стандарты в области выборов, как периодичность выборов, подлинность выборов, свобода и справедливость выборов, соблюдение принципа всеобщего и равного избирательного права и тайна голосования ${ }^{2}$. В документе содержится характеристика этих стандартов.

В Руководстве по наблюдению за выборами (ОБСЕ/БДИПЧ, Варшава, 2005 г.) дана трехчленная классификация международных стандартов в электоральной сфере: всеобщие принципы выборов и прав человека ОOH; обязательства ОБСЕ; другие международные обязательства ${ }^{3}$.

Более удачная попытка сформулировать международные избирательные стандарты предпринята в части 2 статьи 1 Конвенции о стандартах демократических выборов, избирательных прав и свобод в государствах - участниках СНГ. В данном документе указано, что «стандартами демократических выборов являются: право гражданина

${ }^{1}$ Международные избирательные стандарты. Сб. документов / Отв. ред.: доктор юрид. наук В.И. Лысенко. М.: ЦИК России, 2009. С. 241-243.

2 Международные избирательные стандарты. Сб. документов / Отв. ред.: доктор юрид. наук В.И. Лысенко. М.: ЦИК России, 2009. С. 780-781.

${ }_{3}^{3}$ Международные избирательные стандарты. Сб. документов / Отв. ред.: доктор юрид. наук В.И. Лысенко. М.: ЦИК России, 2009. С. 639-641. 
избирать и быть избранным в органы государственной власти, органы местного самоуправления, в иные органы народного (национального) представительства; принципы периодичности и обязательности, справедливости, подлинности и свободы выборов на основе всеобщего равного избирательного права при тайном голосовании, обеспечивающие свободу волеизъявления избирателей; открытый и гласный характер выборов; осуществление судебной и иной защиты избирательных прав и свобод человека и гражданина, общественного и международного наблюдения за выборами; гарантии реализации избирательных прав и свобод участников избирательного процесса». На основе обобщения и содержательного развития общепризнанных принципов и норм международного права, в том числе международных обязательств государств - участников СНГ в рамках ООН, ОБСЕ, Совета Европы, Межпарламентского Союза, обобщения опыта конституционного и правового регулирования выборов в государствах - участниках СНГ демократические стандарты оценки качества национального избирательного законодательства, подготовки и проведения выборов, обеспечения избирательных прав и свобод граждан, гарантий их реализации были сведены в формат единого целевого систематизированного международно-правового документа обязательного характера ${ }^{1}$. В Конвенции закреплено стремление государств создавать систему правовых, организационных и информационных гарантий обеспечения избирательных прав и свобод граждан при подготовке и проведении выборов любого уровня.

Следует согласиться с И.Б. Борисовым и В.И. Лысенко, по мнению которых «в целом впервые в международно-правовом документе конкретизирован статус международных наблюдателей, установлены их обширные полномочия, определены гарантии, содействующие выполнению

1 Конвенция о стандартах демократических выборов, избирательных прав и свобод в государствах - участниках Содружества Независимых Государств: Документы и материалы. /Отв. ред. В.И. Лысенко. М.: РЦОИТ, 2008. С. 14. 
ими своих функциональных обязанностей для объективного наблюдения за выборами, оценки национального избирательного законодательства, практики проведения выборов, обеспечения избирательных прав и свобод участников избирательного процесса международным обязательствам государства по проведению демократических выборов ${ }^{1}$.

В настоящее время Конвенция о стандартах демократических выборов, избирательных прав и свобод в государствах - участниках СНГ остается «единственным в своем роде документом, четко и однозначно формулирующим избирательные стандарты»² .

Избирательные стандарты разрабатываются в интересах международной поддержки развития национальных демократических институтов народного волеизъявления, оказания помощи национальным государственным органам в создании действенных гарантий реализации избирательных прав и свобод граждан, укрепления сотрудничества государств в области общественного и международного наблюдения за выборами. В этом заключается значимость избирательных стандартов.

Как отмечает В.И. Лысенко, «задачами международной деятельности по выработке норм - стандартов в электоральной сфере являются: создание надлежащих правовых эталонов регулирования отношений, складывающихся по поводу закрепления избирательных прав граждан и демократических избирательных процедур, а именно: устранение нерационального многообразия видов регулирования в области избирательного права на

1 Конвенция о стандартах демократических выборов, избирательных прав и свобод в государствах - участниках Содружества Независимых Государств: Документы и материалы. /Отв. ред. В.И. Лысенко. М.: РЦОИТ, 2008. С. 16.

i Постановление Межпарламентской Ассамблеи государств - участников Содружества Независимых Государств «О совершенствовании системы международного сотрудничества в области демократических выборов» (Санкт-Петербург, 25 октября 2008 г.) // Международные избирательные стандарты. Сб. документов / Отв. ред.: доктор юрид. наук В.И. Лысенко. М.: ЦИК России, 2009. С. 903. Разработанная по инициативе ЦИК России в 2002 г. Европейская конвенция о стандартах выборов, избирательных прав и свобод, в которой содержится аналогичный перечень избирательных стандартов, так и не была рассмотрена Комитетом министров Совета Европы. 
основе общепризнанных и других международных стандартов; создание механизмов, позволяющих доступно взаимно контролировать и «измерять» качество такого регулирования; создание и совершенствование методов воздействия на поведение участников отношений в данной сфере, т.е. гармонизация национального законодательства» ${ }^{1}$.

Размышляя о природе международных избирательных стандартов, Ю.А. Веденеев пишет: «Международные избирательные стандарты адресованы одновременно и государству, обязывая его обеспечить граждан адекватным природе демократического политического процесса объективным правом, и гражданам, предоставляя и гарантируя им определенные юридические возможности, т.е. субъективные политические права» ${ }^{2}$.

Обязательность международных стандартов связана с особенностями правосубъектности государства в международных отношениях, поскольку участие государства в функционировании тех или иных международных организаций и соответствующих договорных отношениях налагает на него политические или юридические обязательства.

В настоящее время существует несколько десятков международных актов, регулирующих организацию демократических выборов, которые являются для Российской Федерации юридически или политически обязывающими.

Среди универсальных избирательных стандартов наиболее важными источниками международного права для Российской Федерации являются: Всеобщая декларация прав человека 1948 г.; Международный пакт о гражданских и политических правах 1966 г.; Конвенция ООН о политических правах женщин 1952 г.; Международная конвенция ООН о ликвидации всех форм расовой дискриминации 1965 г.; Декларация Межпарламентского

1 Международные избирательные стандарты. Сб. документов / Отв. ред.: доктор юрид. наук В.И. Лысенко. М.: ЦИК России, 2009. С. 23.

${ }_{2}$ Веденеев Ю.А. Развитие избирательной системы Российской Федерации: проблемы правовой институционализации // Журнал российского права. 2006. № 6. С. 56. 
союза о критериях свободных и справедливых выборов 1994 г.; Декларация принципов международного наблюдения за выборами 2005 г.

Основополагающие региональные избирательные стандарты представлены документами ОБСЕ (Документ Копенгагенского совещания Конференции по человеческому измерению СБСЕ 1990 г.; Документ Будапештской встречи на высшем уровне 1994 г.; Руководство БДИПЧ /ОБСЕ по наблюдению за выборами 2005 г.; Руководство БДИПЧ /ОБСЕ для долгосрочных наблюдателей за выборами 2007 г.), Совета Европы (Конвенция о защите прав человека и основных свобод 1950 г.), Европейского Союза (Хартия Европейского Союза об основных правах 2000 г.), Содружества Независимых Государств (Конвенция о стандартах демократических выборов, избирательных прав и свобод в государствах участниках СНГ 2002 г.; Декларация Межпарламентской Ассамблеи государств СНГ «О принципах международного наблюдения за выборами и референдумами в государствах - участниках Содружества Независимых Государств» 2008 г.). Данный комплекс международных актов составляет основу современных демократических выборов.

Соотношение международного и национального аспектов в правовом регулировании избирательного процесса можно определить, обратившись к Конституции Российской Федерации.

Согласно части 4 статьи 15 Конституции Российской Федерации общепризнанные принципы и нормы международного права и международные договоры Российской Федерации являются составной частью ее правовой системы. Если международным договором Российской Федерации установлены иные правила, чем предусмотренные законом, то применяются правила международного договора. Данная трансформационная норма означает, что вступление международных договоров Российской Федерации в силу и возникновение новых общепризнанных норм международного права влекут для России внутригосударственное правотворчество. 
В соответствии с нормативным толкованием Пленума Верховного Суда Российской Федерации «под общепризнанными принципами международного права следует понимать основополагающие императивные нормы международного права, принимаемые и признаваемые международным сообществом государств в целом, отклонение от которых недопустимо. Под общепризнанной нормой международного права следует понимать правило поведения, принимаемое и признаваемое международным сообществом государств в целом в качестве юридически обязательного» ${ }^{1}$.

Как отмечается в Постановлении Пленума Верховного Суда Российской Федерации от 10 октября 2003 г. № 5 первостепенная роль в сфере защиты прав человека и основных свобод принадлежит международным договорам.

Международные договоры, обязательные для Российской Федерации, официально публикуются в Собрании законодательства Российской Федерации или в Бюллетене международных договоров. Официальные сообщения Министерства иностранных дел Российской Федерации о вступлении в силу международных договоров, заключенных от имени Российской Федерации и от имени Правительства Российской Федерации, подлежат опубликованию в том же порядке, что и международные договоры.

Согласно части 3 статьи 5 Федерального закона «О международных договорах Российской Федерации» положения официально опубликованных международных договоров Российской Федерации, не требующие издания внутригосударственных актов для применения, действуют в Российской Федерации непосредственно. Для осуществления иных положений международных договоров Российской Федерации принимаются соответствующие правовые акты (федеральные законы или подзаконные акты).

${ }^{1}$ Постановление Пленума Верховного Суда Российской Федерации от 10 октября 2003 г. № 5 «О применении судами общей юрисдикции общепризнанных принципов и норм международного права и международных договоров Российской Федерации» // Рос. газ. 2003. 2 декабря. 
Правила действующего международного договора Российской Федерации, согласие на обязательность которого было принято в форме федерального закона, имеют приоритет в применении в отношении законов Российской Федерации. Другие международные договоры Российской Федерации, согласие на обязательность которых принято не в форме федерального закона, имеют приоритет по отношению к подзаконным нормативным актам, изданным органом государственной власти, заключившим данный договор.

Особенностью большинства международных избирательных стандартов является отсутствие императивных норм, регулирующих конкретные избирательные процедуры и действия. Это означает, что, ориентируясь на международные стандарты, государство может самостоятельно регулировать национальный избирательный процесс (закреплять те или иные избирательные системы на выборах разных уровней, регламентировать особенности выдвижения и регистрации кандидатов (списков кандидатов), определять структуру и состав органов народного представительства и др.).

Вместе с тем, признание юрисдикции международных организаций не должно противоречить целям достижения внутренних национальных интересов государства, основанных на положениях его конституции. Международное право, будучи инкорпорированным по воле государства в его национальную правовую систему, не должно игнорировать цели и принципы данной правовой системы. В связи с этим нормы международного права должны толковаться и применяться на внутригосударственном уровне как с точки зрения целей и принципов международного права, так и согласно соответствующим ориентирам внутригосударственного права ${ }^{1}$.

Рассматривая соотношение международного и национального аспектов в правовом регулировании избирательного процесса, выделим ряд проблем,

${ }^{1}$ Борисов И.Б. Указ. соч. С. 121-122. 
связанных с трансформацией положений международных правовых актов в исследуемой области в российскую правовую систему.

Первостепенное значение для защиты конституционного строя имеет проблема пределов ограничения суверенных электоральных прав Российской Федерации в пользу правовых предписаний международных нормативных документов. Представляется, что главную роль в экспертизе соответствия международных договоров Российской Федерации в сфере выборов Конституции России должны играть Министерство юстиции, Федеральное Собрание и Конституционный Суд Российской Федерации. $\mathrm{He}$ соответствующие Конституции России международные договоры Российской Федерации не должны ратифицироваться и применяться.

Актуальной является проблема гармонизации международной и национальной источниковой базы регулирования избирательного процесса. Потребность в ее решении обусловлена двумя обстоятельствами.

Во-первых, согласно международным стандартам, правовые нормативы, обеспечивающие проведение выборов, не могут устанавливаться актами исполнительной власти. Между тем, в ряде государств СНГ (Азербайджан, Беларусь, Кыргызстан, Российская Федерация, Таджикистан) и Европы (Великобритания, Испания, Италия, Нидерланды) важное значение для регламентации избирательного процесса имеют подзаконные нормативные правовые акты, которые издаются на основе и во исполнение законов, являясь формой реализации компетенции субъектов правотворчества.

Во-вторых, несовершенство существующей методологии иностранного (международного) наблюдения за выборами, нечеткость критериев оценки избирательного процесса для всех государств мирового сообщества ставят на повестку дня вопрос о кодификации международных стандартов в электоральной сфере и более подробной регламентации иностранного и международного участия во внутригосударственном избирательном процессе. 
В целях установления точного содержания принципов и норм международного права в электоральной сфере, содержательного развития и правового закрепления этих принципов и норм по инициативе ЦИК России в 2002 г. была подготовлена Европейская конвенция о стандартах выборов, избирательных прав и свобод, которая после положительного заключения Венецианской комиссии Совета Европы в 2004 г. была внесена на рассмотрение Парламентской Ассамблеи Совета Европы. Однако до сих пор этот проект так и не был рассмотрен Комитетом Министров Совета Европы.

В 2007 г. государства - участники Организации Договора о коллективной безопасности (ОДКБ) предложили на рассмотрение ОБСЕ «Базовые принципы организации наблюдения за общенациональными выборами по линии БДИПЧ ОБСЕ», направленные на дальнейшее развитие универсальных демократических стандартов и обеспечение прав каждого государства на суверенитет в электоральных процессах ${ }^{1}$. Подготовленный документ, к сожалению, также не был принят.

Несмотря на политизированность существующих межгосударственных отношений в электоральной сфере и проявления селективных подходов в мониторинговой деятельности международных организаций, блоковое мышление и менторский тон в отношении прав человека и демократических институтов постепенно уступают место конструктивному сотрудничеству государств по созданию и обеспечению избирательных стандартов, равноправным отношениям по линии организации и проведения выборов на базе существующих международных документов.

Гармонизация международной и национальной правовой базы призвана способствовать выработке общих подходов к вопросу о сближении избирательного законодательства, развитию демократических традиций народного волеизъявления на выборах на основе реального политического плюрализма и многопартийности, в условиях верховенства Конституции и национальных законов, опирающихся на общепризнанные нормы и принципы международного права.

${ }^{1}$ Борисов И.Б. Электоральный суверенитет. М.: РОИИП, 2010. С. 51. 